\title{
Thrombocytagátló és antikoagulációs terápia a szívsebészetben napjainkban
}

\author{
Tóth Roland dr. ${ }^{1}$ - Németh Zoltán dr. ${ }^{2}$ - Rashed Aref dr. ${ }^{1}$ \\ ${ }^{1}$ Zala Megyei Szent Rafael Kórház, Szívsebészeti Osztály, Zalaegerszeg \\ ${ }^{2}$ Zala Megyei Szent Rafael Kórház, Kardiológiai Osztály, Zalaegerszeg
}

\begin{abstract}
Egy szívműtét tervezésekor és a perioperatív időszakban egyaránt kiemelkedő jelentősége van a megfelelő thrombocytagátló és antikoaguláns kezelés alkalmazásának. Írásunk célja összefoglalni és ismertetni a jelenleg érvényes nemzetközi ajánlásokat és a jelentős tanulmányok eredményeit, összpontosítva a Magyarországon alkalmazásban lévő gyakorlatra. A bizonyítékokon alapuló iránymutatások alábbi, legújabb adatai döntően a European Association for Cardio-Thoracic Surgery és a European Society of Cardiology ajánlásaira épülnek, ezeket kiegészítettük az American College of Cardiology, az American Heart Association és a Society of Thoracic Surgeons útmutatásaival, végül egyes témákban hozzáfüztük az elmúlt időszak meghatározó tanulmányainak főbb eredményeit. Cikkünkben érintjük a mono- és kettős thrombocytagátló, továbbá az oralis antikoaguláns kezelés szerepkörét, beleértve az új típusú thrombocytagátló és oralis antikoaguláns gyógyszereket, valamint az áthidaló terápia fontosságát az antikoagulálásban, a különböző típusú beültetett szívbillentyúk esetén betartandó antikoagulálási ajánlásokat, valamint kitérünk a perioperatív pitvarfibrilláció, a posztoperatív thrombosisprofilaxis és a vérzésveszély esetén történő gyógyszeres kezelés témájára. Figyelembe veendő, hogy a jelen információk folyamatos frissítésen mennek keresztül, a lenti javaslatok csupán a jelen helyzetet mutatják be.
\end{abstract}

Orv Hetil. 2021; 162(48): 1910-1919.

Kulcsszavak: szívsebészet, thrombocytagátlás, antikoagulálás, protokoll

\section{Current antiplatelet and anticoagulation therapy in the field of cardiac surgery}

The use of appropriate antiplatelet and anticoagulant therapy has got an outstanding role both in the planning of cardiac surgery and also during the perioperative period. The aim of our paper is to summarize and present the current international recommendations and the results of significant studies, focusing on the current practice in Hungary. The following informations are based on the evidence-based guidelines and recommendations of the European Association for Cardio-Thoracic Surgery and the European Society of Cardiology, supplemented by guidelines from the American College of Cardiology, the American Heart Association and the Society of Thoracic Surgeons, finally we added some topics from the main results of major studies of the last years. In this paper, we discuss the role of mono- and dual anti-platelet and oral anticoagulant therapy, including the mechanism of novel antiplatelet and oral anticoagulant drugs, the importance of bridging therapy in anticoagulation, postoperative thrombosis prophylaxis and the medication practice in the case of bleeding risk. It should be noted that though the present information has been recently updated, the suggestions below only illustrate the current state of evidence.

Keywords: cardiac surgery, anti-platelet therapy, anticoagulation, protocol

Tóth R, Németh Z, Rashed A. [Current antiplatelet and anticoagulation therapy in the field of cardiac surgery]. Orv Hetil. 2021; 162(48): 1910-1919.

(Beérkezett: 2021. április 8.; elfogadva: 2021. május 11.)

\section{Rövidítések}

ACC $=($ American College of Cardiology $)$ Amerikai Kardiológiai Társaság; $\mathrm{ACS}=$ akut coronaria szindróma; $\mathrm{ADP}=($ adenosine diphosphate) adenozin-difoszfát; $\mathrm{AHA}=$ American Heart
Association) Amerikai Szívgyógyász Szövetség; AMI = (acute myocardial infarction) akut myocardialis infarctus; ASA = (acetylsalicylic acid) acetilszalicilsav; $\mathrm{CABG}=($ coronary artery bypass grafting) koszorúér-áthidaló mütét; $\mathrm{CCS}=$ (Canadian 
Cardiovascular Society) Kanadai Cardiovascularis Társaság; $\mathrm{CHA}_{2} \mathrm{DS}_{2}$-VASc $=$ Congestiv szívelégtelenség, Hypertonia, Életkor (Age), Diabetes mellitus, Stroke, Vascularis betegség, Életkor (Age), Női nem (Sex); DAPT $=$ (dual anti-platelet therapy) kettős thrombocytagátló terápia; $\mathrm{DOAC}=$ (direct oral anticoagulant) direkt hatású oralis antikoaguláns; EACTS $=($ European Association for Cardio-Thoracic Surgery) Európai Szív-Mellkas Sebészeti Társaság; ESC = (European Society of Cardiology) Európai Kardiológiai Társaság; GFR = glomerulusfiltrációs ráta; GP = glikoprotein; $\mathrm{INR}=$ (international normalized ratio) nemzetközi normalizált ráta; $\mathrm{LMWH}=$ (low molecular weight heparin) kis molekulatömegü heparin; MACE $=$ (major adverse cardiovascular event $)$ súlyos cardiovascularis esemény; $\mathrm{NE}=$ nemzetközi egység; NSTEMI = (non-ST-elevation myocardial infarction) ST-elevációval nem járó myocardialis infarctus; $\mathrm{OAC}=$ (oral anticoagulant) oralis antikoaguláns; $\mathrm{PCI}=$ percutan coronariaintervenció STEMI = (ST-elevation myocardial infarction) ST-elevációval járó myocardialis infarctus; STS $=$ (Society of Thoracic Surgeons) Mellkasi Sebészek Társasága; TTR $=$ (time in therapeutic range $)$ terápiás tartományban töltött idő; UFH = (unfractionated heparin) nem frakcionált heparin; VKA = (vitamin $\mathrm{K}$ antagonist $)$ K-vitamin-antagonista

A szívsebészeti beavatkozásokhoz kötődő antikoagulálási módszerek elemzésével számos vezérfonalra és sok nemzetközi tanulmány eredményeire támaszkodhatunk. Az alábbi összefoglalásban található információk döntően a European Association for Cardio-Thoracic Surgery (EACTS) és a European Society of Cardiology (ESC) ajánlásaira épülnek, kiegészítve az American College of Cardiology (ACC) és az American Heart Association (AHA), továbbá a Society of Thoracic Surgeons (STS) útmutatójából származó adatokkal és egyéb nagy vizsgálatok eredményeivel.

\section{Thrombocytagátló kezelés a szívsebészetben}

Fontos szempont a thrombocytagátlók szívsebészeti vonatkozásában az, hogy a mútét előtt azok adását felfüggesztjük-e, vagy tovább adjuk egészen a beavatkozásig („stop or proceed?”). A kérdésben hangsúlyozott kell, hogy legyen az egyedi elbírálás jelentősége (például a beavatkozás sürgőssége, koszorúér-morfológia alapján), és feltétlenül ajánlott, hogy egy „heart team” közösen vitassa meg a szívmútétre kerülő beteg mútét előtti antithromboticus kezelésének optimális ütemezését a várható ischaemiás/thromboemboliás/vérzéses kockázat függvényében (I/C evidencia) [1].

Szintén kiemelt fontosságú, hogy amennyiben a thrombocytagátlókat (és/vagy más antithromboticus gyógyszereket) nem hagyjuk el, meg kell becsülnünk a vérzéses szövődmények fokozott kockázatát a thrombosis potenciálisan megnövekedett kockázatával szemben, és hagyatkoznunk kell a „point of care” (ágy melletti) thrombocytafunkció-tesztek eredményeire a túlzott mértékû transzfúzió elkerülése érdekében [1, 2]. Az utóbbi jelentôségét az adja, hogy a szívmútét kapcsán adott vörösvérsejt-transzfúzió és az infekciós, továbbá a szív- és légzőszervi szövődmények, a hosszabb tartózkodási idő és a mortalitás között független összefüggés áll fenn, így a mútét várható kedvező hatása jelentős mértékben csökkenhet [3]. A fenti tesztek segítségével optimalizálható a mútét időzítése, különösen olyan betegek esetében, akiknél a P2Y12-receptor-gátló elhagyása óta eltelt idő nem tisztázott; egyéni különbségek miatt a preoperatív thrombocytafunkció-teszt alkalmazása klopidogrélt szedő betegek esetén akár 50\%-kal lerövidítheti a mútétre való várakozás idejét, így elvégzése mérlegelendő a közvetlen preoperatív időszakban a szívmútét időzítésének meghatározására (IIb/B szintű ajánlás, vagyis alkalmazása a kezelőorvos döntése lehet) [1].

Adott esetben fontos különbséget tennünk az egyes mútéttípusok és a thrombocytagátló kezelés formája között. Jó példa erre a különböző technikával végzett koszorúér-áthidaló mútétek (CABG) esete, hiszen stabil ischaemiás szívbetegséggel bíró betegeknél, válogatott esetekben (például coronariaendarterectomia, „offpump" [vagyis dobogó szíven végzett] CABG-mưtét) a nagyobb ischaemiás kockázat következtében mérlegelendővé válik a DAPT adása (IIb/C szintû ajánlás) [1].

$\mathrm{Az}$ alábbiakban részletesen ismertetjük a hazai szívgyógyászati gyakorlatban két leggyakrabban alkalmazott thrombocytagátló fóbb vonatkozásait, és kitérünk további, újabb típusú P2Y12-receptor-gátlók tulajdonságaira.

\section{Acetilszalicilsav (ASA)}

A CABG-mútét előtti ASA-val történő kezelés csökkenti a perioperatív akut myocardialis infarctus (AMI) kockázatát, de nem csökkenti a mortalitást, CABG előtti szedése kapcsán pedig nő a posztoperatív vérzés, a vörösvértest-transzfúzió és az újbóli mellkasnyitás aránya [4]. A nagyobb dózisú ( $\geq 300 \mathrm{mg}$ ) ASA jelentősen növeli a vérzés veszélyét, de csökkenti a súlyos cardiovascularis események (MACE) előfordulásának arányát [5]. Az ASA-nak a mútét előtt 5 nappal való felfüggesztése esetén kis molekulatömegű heparinnal (LMWH) való helyettesítése növeli a vérzéses szövődmények rizikóját, így a módszer nem ajánlott [6]. Az ASA thrombocytaaggregációra gyakorolt hatása egyértelmúen befolyásolható thrombocyta-transzfúzióval, ami szintén az ASA (akár elektív) mútétig való adása mellett szól CABG-mútét előtt álló betegeknél [1]. Mérlegelni szükséges az ASAnak legalább 5 nappal a mütét előtt való leállítását azoknál, akik nem CABG-mútétre várnak, és nagy vérzéses kockázattal bírnak (komplex és redomútétek, súlyos vesekárosodás, hematológiai betegség, thrombocyta-rendellenesség), vagy megtagadják a transzfúziót [7].

Egyes adatok szerint a mütét utáni első 48 órában ASA-t kapó CABG-s betegek mortalitása 1,3\% az ebben az időszakban ASA-t még nem kapó betegek 4,0\%-os halálozásával szemben [8]. A posztoperatív ASA-terápia 
48\%-kal csökkenti az AMI előfordulását, 50\%-kal a stroke-ét, 74\%-kal a vesekárosodásét és 62\%-kal a bélinfarktusét [8]. Az ASA CABG-mütét utáni első 6 órán belüli megadása a bypassgraftok jobb átjárhatóságához vezet a vérzéses szövődmények arányának emelkedése nélkül [9]. Amint a vérzésveszély megszünt, az ASA-t minden, CABG után álló betegnek szükséges megadni; alkalmazásának fóbb iránymutatásait Sousa-Uva és mtsai foglalták össze [1].

\section{P2Y12-receptor-gátlók (ADP-antagonisták), kettôs thrombocytagátló kezelés (DAPT)}

Az ASA-val és P2Y12-receptor-gátlókkal (klopidogrél, praszugrél, tikagrelor, kangrelor) végzett DAPT az ASAval monoterápiában történő kezeléssel összehasonlítva csökkenti a thromboticus szövődmények kockázatát az akut coronaria szindrómában (ACS) szenvedő betegeknél, különösen percutan coronariaintervenció (PCI) kapcsán $[10,11]$. A thrombosisos szövődmények kockázata tovább csökken, ha a klopidogrél helyett hatékonyabb, harmadik generációs P2Y12-gátlót (praszugrél vagy tikagrelor) alkalmazunk, mindez azonban növeli a spontán és perioperatív vérzéses szövődmények kialakulásának veszélyét $[10,11]$. A jelenleg érvényes irányelvek alapján a DAPT minden, ACS-ben szenvedő beteg számára javasolt, függetlenül a revascularisatio típusától $[12,13]$. Ez az ajánlás vonatkozik a CABG utáni ido"szakra és az egyéb szívmútéteket követően egyaránt.

STEMI-t vagy NSTEMI-t követően ajánlott a DAPT ASA és tikagrelor vagy praszugrél formájában (az utóbbi kettő ellenjavallata esetén klopidogrél adandó) PCI (I/A evidencia) és CABG (I/C evidencia) után egy évig, kivéve bizonyos ellenjavallatok (nagyon magas vérzésrizikó) esetén; ebben az esetben a DAPT CABG után ASA és tikagrelor vagy klopidogrél formájában 6 hónapig adandó, ezt követóen a DABT elhagyása megfontolandó (IIa/C evidencia) $[1,14]$.

CABG utáni DAPT esetén alacsonyabb mortalitási rátáról és vénagraftok esetében jobb nyitvamaradási arányról számoltak be [15]. A DAPT fenti előnyös hatásait csökkenti a vérzéses szövődmények kockázatának meg- növekedése [1]. A P2Y12-receptor-gátlókkal való kezelés hatékonysága, így a mortalitás több mint 50\%-os csökkenése kifejezettebb az ACS-ben szenvedő betegekben, mint a stabil anginás panasszal rendelkezőkben és abban az esetben is, ha a klopidogrélnél hatékonyabb P2Y12-receptor-gátlókat alkalmazunk [15].

A DAPT-nak a mútét időpontjáig való folytatása növeli a vérzés, a transzfúzió és a vérzés miatti reoperáció kockázatát, így elektív mútét előtt, amikor csak lehetséges, ajánlott a P2Y12-receptor-gátlók elhagyása [12, 13, 16, 17]. Elektív mütét esetében a beavatkozás a DAPT hatásának lecsengéséig elhalasztható; legfeljebb 1-2 nap várakozást megengedő sürgető mütét esetén a P2Y12receptor-gátlók hatásának felfüggesztése kapcsán a thromboemboliás (sztentthrombosis, AMI) és a vérzéses kockázat arányának megítélése szükséges a döntés meghozatalához [1]. Kiemelten magas thrombosiskockázat (például PCI a közelmúltban) esetén megfontolandó az áthidaló kezelés választása, vagy a mútét elvégezhető a P2Y12-receptor-gátlók abbahagyása nélkül [1, 12-14]. Amennyiben az áthidalás indokolt, erre a célra GPIIb/ GPIIIa inhibitorok használhatók [1]. Az utóbbiak alkalmazása az itthoni gyakorlatban nem jellemző. DAPT esetén, amennyiben a P2Y12-receptor-gátlót elhagyjuk, az ASA-monoterápiát a mütétig folytatni szükséges [16]. A klopidogrélnek a CABG-mútét előtt legalább 5 nappal való elhagyása esetén a posztoperatív vérzéses szövődmények kockázata nem növekszik; praszugrél esetén legalább 7 napos elhagyási intervallum szükséges, míg tikagrelor esetén 3-4 nap az ajánlott (1. táblázat) [17, 18]. Thrombocytafunkció-teszt segítségével optimalizálható a mütét időzítése, különösen olyan betegek esetében, akiknél a P2Y12-receptor-gátló elhagyása óta eltelt idő nem tisztázott [1].

Az európai és amerikai ajánlások mellett a témában a Canadian Cardiovascular Society (CCS) is állást foglal: DAPT esetén a klopidogrél mütét előtti elhagyását kizárólag alacsony ischaemiás rizikóval bíró betegeknél hagyja jóvá, illetve mérlegelendővé teszi magas vérzéses rizikó esetén [19].

ACS-ben szenvedő betegek esetén, CABG-t követően, a DAPT újraindítása történjen meg, amint az biztonságosnak tekinthető [1]. Jelenleg nincs bizonyíték arra,

1. táblázat |A P2Y12-receptor-gátlók fő tulajdonságai

\begin{tabular}{llll}
\hline & $\begin{array}{l}\text { Klopidogrél } \\
\text { (Plavix, Zyllt, Plagrel) }\end{array}$ & $\begin{array}{l}\text { Praszugrél } \\
(\text { Efient })\end{array}$ & $\begin{array}{l}\text { Tikagrelor } \\
\text { (Brilique) }\end{array}$ \\
\hline Felezési idő & 1-2 óra & $2-15$ óra & 7-9 óra \\
\hline Kötődés & Irreverzibilis & Irreverzibilis & Reverzibilis \\
\hline A hatás kezdete & $2-6$ óra & 30 perc & 30 perc \\
\hline Adagolás & Napi $1 \times$ & Napi $1 \times$ & Napi $2 \times$ \\
\hline A hatás tartóssága & $3-10$ nap & $7-10$ nap & $3-5$ nap \\
\hline Antidotum & Nincs & Nincs & Nincs \\
\hline Mütét elótti elhagyása & Min. 5 nap & Min. 7 nap & Min. 3 nap \\
\hline
\end{tabular}




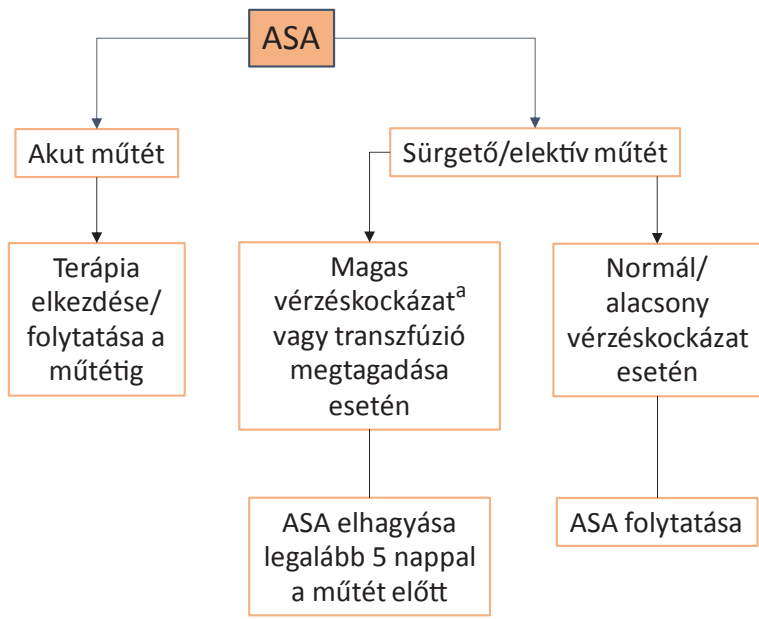

${ }^{a}$ Komplex és redomútétek, súlyos veseelégtelenség, hematológiai és örökletes vérlemezkefunkció-eltérések

${ }^{\mathrm{b}}$ Közelmúltban végzett sztentbeültetés vagy thromboemboliás esemény, illetve nagyon súlyos koronarográfiáslelet

cAmíg a DAPT-nak megfelelő időszak le nem telik

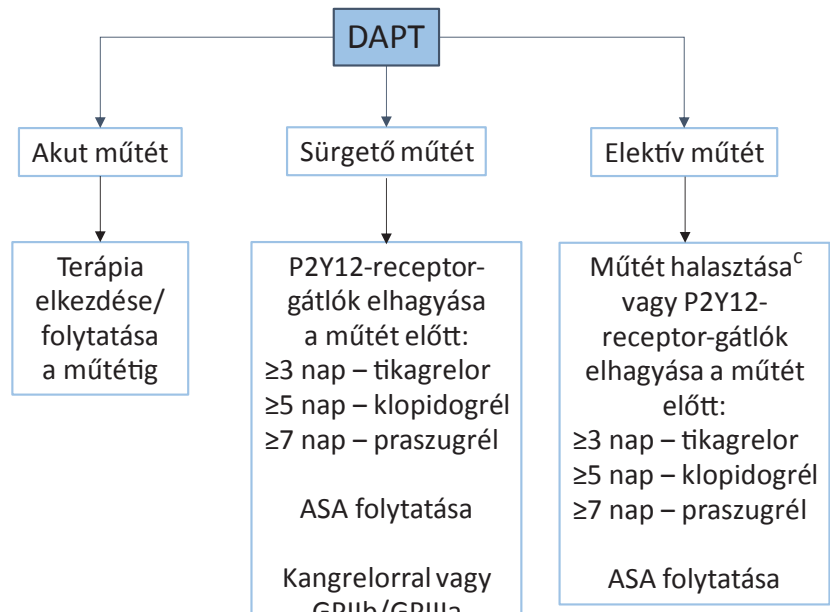

GPIIb/GPIIla

inhibitorral való

áthidaló terápia

megfontolása

magas

thromboemboliás

rizikó esetén ${ }^{b}$

1. ábra $\mid$ A kettős thrombocytagátló terápia szabályozása CABG-mútétet megelőzően

ASA = acetilszalicilsav; $\mathrm{CABG}=$ koszorúér-áthidaló mútét; DAPT = kettős thrombocytagátló terápia; GP = glikoprotein

hogy azoknál a CABG-n átesett betegeknél, akik preoparatíve nem részesültek DAPT-ban, annak rutinszerü posztoperatív beállítását szorgalmazni kellene, megfontolandó azonban azoknál a betegeknél, akik coronariaendarterectomián vagy „off-pump” CABG-mütéten estek át [1]. A terápia újraindításának optimálisan a lehető leghamarabb meg kell történnie, amikor azt biztonságosnak ítéljük meg [1]. A nagy ischaemiás kockázatú betegeknél a P2Y12-receptor-gátlókat a mútét utáni első 48 órán belül vissza kell adni [1]. Alacsony ischaemiás kockázat mellett (például a PCI óta eltelt idő >1 hónap, vagy ACS esete PCI nélkül) biztonságosnak tekinthető a P2Y12-receptor-gátlók visszaadása 3-4 nappal a mútét után [1]. A P2Y12-receptor-gátlókkal és DAPT-val kapcsolatosan nemzetközi ajánlások adnak segítséget, a CABG-mútéthez kötödő információkról pedig az 1 . ábra ad áttekintést $[1,14]$.
2. táblázat |A K-vitamin-antagonisták fó tulajdonságai

\begin{tabular}{lll}
\hline & Acenokumarol & Warfarin \\
\hline Féléletidő & 10 óra & $35-80$ óra \\
Kezdő dózis & $4 \mathrm{mg}$ & $5 \mathrm{mg}$ \\
A terápiás egyensúly kialakulása & $2-3$ nap & $3-6$ nap \\
Hatástartam & $2-4$ nap & $4-5$ nap \\
\hline
\end{tabular}

\section{Antikoagulálás a preoperatív időszakban, áthidaló terápia}

K-vitamin-antagonistákkal (VKA) kezelt betegeknél a VKA-t elektív mútét előtt 5 nappal szükséges leállítani ahhoz, hogy a mütét napján a beteg INR-értéke jó esélylyel 1,5 alatti legyen (2. táblázat) [20]. Nem VKA, új típusú oralis antikoagulánsokkal (DOAC) kezelt bete-

3. táblázat | Az új típusú oralis alvadásgátlók fő tulajdonságai

\begin{tabular}{llll}
\hline & Apixabán (Eliquis) & Dabigatrán (Pradaxa) & Edoxabán (Lixiana) \\
\hline Hatás & Xa-faktor & Trombin & Xa-faktor \\
\hline Max. koncentráció & 3 óra & 2 óra & $1-3$ óra \\
\hline Féléletidő & $9-14$ óra & $14-17$ óra & $5-11$ óra \\
\hline Adagolás & Napi $2 \times$ & Napi $1 \times$ v. $2 \times$ & Napi $1 \times$ \\
\hline Renalis excretio & $25 \%$ & $80 \%$ & $36-45 \%$ \\
\hline Antidotum & Andexanet-alfa & Idarucizumab & Andexanet-alfa \\
\hline Mütét elótti elhagyása & Min. 48 óra & Min. $48-96$ óra* & Min. 48 óra \\
\hline
\end{tabular}

*: >48 óra, ha CCl >80 ml/min/1,73 m²; >72 óra, ha CCl 50-79 ml/min/1,73 m²; >96 óra, ha CCl<50 ml/min/1,73 m²

$\mathrm{CCl}=$ kreatininclearance 
geknél az elektív szívmútét előtt a DOAC-ot a vesefunkciótól és a gyógyszer típusától függően, egyéni idôpontban kell elhagyni (3. táblázat) [21].
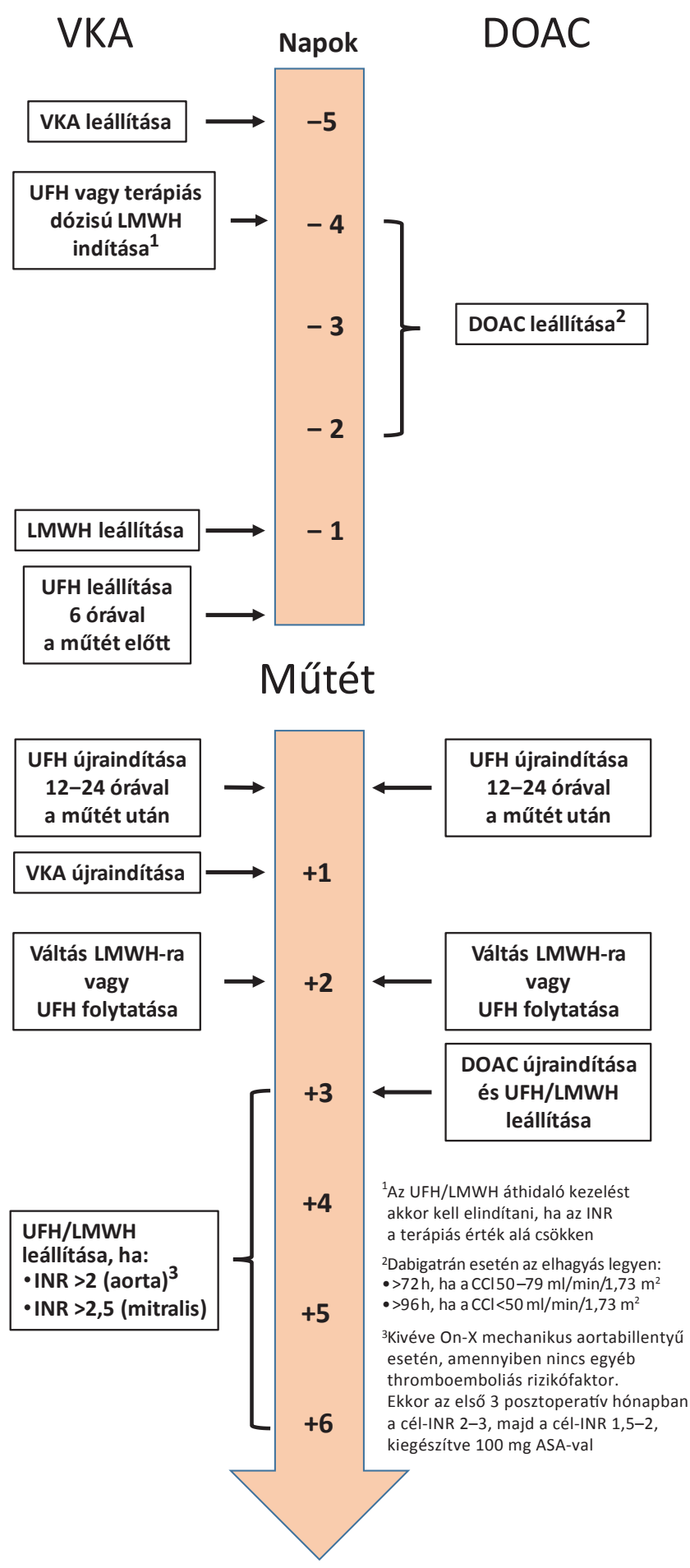

2. ábra

VKA- és DOAC-terápia, illetve áthidaló terápia szívmútét kapcsán (az EACTS módosított ábrája [1])

ASA $=$ acetilszalicilsav; $\mathrm{CCl}=$ kreatininclearance DOAC $=\mathrm{di}-$ rekt hatású oralis antikoaguláns; EACTS = Európai Szív-Mellkas Sebészeti Társaság; INR = nemzetközi normalizált ráta; $\mathrm{LMWH}$ = kis molekulatömegú heparin; UFH = nem frakcionált heparin; $\mathrm{VKA}=\mathrm{K}$-vitamin-antagonista
Annak eldöntése, hogy az oralis antikoaguláció leállítását követően szükséges-e a nem frakcionált heparinra (UFH) vagy LMWH-ra történő átállás, az alapbetegség ischaemiás kockázatától függ. A preoperatív áthidaló terápia fokozza a perioperatív vérzésveszélyt, ezért nem szükséges minden egyes szívmúttétre érkező, antikoaguláns terápiában részesülő beteget heparinra átállítani [22]. Ajánlott az átállítás azoknál a betegeknél, akik mechanikus múbillentyűvel rendelkeznek, valvularis pitvarfibrillációval bírnak (például közepes vagy súlyos mitralis stenosis esetén), pitvarfibrilláció esetén 4-nél magasabb $\mathrm{CHA}_{2} \mathrm{DS}_{2}$-VASc pontszámuk van, vagy az elmúlt 4 héten belül thromboticus eredetú ischaemiás stroke-ot szenvedtek el, továbbá tüdőembolia és ACS esetén [1]. Megfontolandó az átállás a bal kamrai csúcsi thrombuszszal bíró betegek, valamint az antitrombin III-, illetve a protein C- és S-deficientiával élők esetében [1].

Az áthidaló terápiára az egyetlen jóváhagyott szer az UFH. A mútét előtt UFH-terápián lévő betegek esetében alacsonyabb a szívmútét utáni ismételt mellkasnyitást igénylő vérzéses szövődmények aránya, mint az LMWH-t kapó betegeknél [23]. Mivel az UFH azonban csak kórházi körülmények között alkalmazható, míg az LMWH nem igényel kórházi felvételt, az utóbbi használata praktikusabb, és használatát alternatív megoldásként megfontolhatjuk napi kétszeri terápiás adagban, a testtömegnek és a vesemúködésnek megfelelő dozírozással, továbbá szükség esetén az anti-Xa-aktivitás monitorizálásával [1]. Az UFH farmakokinetikája alapján ajánlott a beavatkozás előtt legalább 6 órával befejezni a terápiát, az LMWH abbahagyása pedig - a napi kétszeri adagolás mellett több tanulmányban leírt magas plazmakoncentrációjára való tekintettel - több mint 12 órával korábban történjen [24]. Ha egy beteg sürgető mútét esetén OAC-ot szed, a körülményektól függően akkor is meg kell próbálni annyival eltolni a mútétet, hogy ezzel a rövid késleltetéssel elkerüljük a súlyos vérzéses szövődményeket. Ha a VKA elhagyása nem történt meg időben, protrombinkomplex-koncentrátum adása szükséges, kiegészítve Kl-vitaminnal [25].

DOAC-ot szedő betegek esetében a már korábban ismertetetteknek megfelelően ellenőrizni kell az utolsó gyógyszerbevétel és a tervezett mútét között eltelt időt, az aktuális GFR-szintet, és meg kell határozni a kezelési koncentrációt, dabigatrán esetén hígított trombinidő, a Xa-faktor-gátlók esetén pedig kromogén Xa-antifaktorassay-k segítségével, így ítélhető meg a gyógyszeraktivitás szintje és a vérzés kockázata [26]. Amennyiben magas DOAC-koncentrációt kapunk, de a mútét nem halasztható, akkor mind az aktivált, mind a nem aktivált protrombinkomplex-koncentrátumok alkalmazása szóba jön, bár a kezelés körülményeinek részletei egyelőre nem teljesen tisztázottak (a kezelés időtartama, megnövekedett thrombosiskockázat, monitorozás stb.) [27]. A fentiekről a 2. ábra ad összefoglalót. 


\section{Antikoagulálás a posztoperatív időszakban, áthidaló terápia}

A billentyưmútétek növelik a thromboemboliás szövődmények kockázatát, ezért ilyenkor antithromboticus kezelésre van szükség. A leginkább megfelelő antithromboticus stratégia módjáról és annak időtartamáról relatíve kevés tudományos bizonyíték áll rendelkezésre, így az ajánlások alacsony evidenciaszinttel bírnak [28].

\section{Mechanikus billentyük}

A mechanikusbillentyú-implantáción átesett betegeknek élethosszig tartó, INR-érték által meghatározott VKAkezelésben kell részesülniük [29]. Az UFH-val és VKAval történő együttes antikoagulációs terápiát az első posztoperatív napon kell elkezdeni, és addig szükséges folytatni, amíg el nem érjük a terápiás INR-t. A heparin (UFH vagy LMWH) elhagyása csak két egymást követő napon mért terápiás INR esetén történhet meg [30]. Különös figyelmet kell szentelni a beteg alvadási statusára és a vérzéses eseményekre. Vérzéses eseményt követően a felfüggesztett VKA-t mielőbb vissza kell adni, amint az biztonságosan megtehető (lehetőleg 48 órán belül) [1]. A preoperatív helyzethez hasonlóan a mechanikus billentyư beültetése után is az intravénás UFH adása az egyetlen jóváhagyott áthidaló terápiás kezelés, az aktivált parciális tromboplasztinidő normálértékének 1,5-2-szerese a szükséges elérendő tartomány [31]. A subcutan LMWH-val való áthidaló terápiát egyszerúbb kivitelezhetősége miatt széles körben alkalmazzák az UFH-val szemben. A subcutan enoxaparin jól alkalmazható a már terápiás antikoagulációban részesülő betegeknél a VKA átmeneti leállításakor: ekkor hasonló vagy nagyobb biztonságot nyújt, mint az UFH, így megfontolható az LMWH használata az UFH terápiás alternatívájaként, alkalmazása azonban „off-label” (indikáción túli) felhasználásnak felel meg [28, 32]. Az LMWH terápiás dozírozása enoxaparin esetén a következők szerint történik: $1 \mathrm{mg} / \mathrm{ttkg}$, subcutan adagolva, naponta kétszer. Ha a GFR $<30 \mathrm{ml} / \mathrm{min} / 1,73 \mathrm{~m}^{2}$, a dózist naponta egyszer 1 $\mathrm{mg} /$ ttkg-ra szükséges csökkenteni. Amennyiben a GFR $<15 \mathrm{ml} / \mathrm{min} / 1,73 \mathrm{~m}^{2}$, az LMWH nem használandó. Az anti-Xa-aktivitás ellenőrzése nem szükséges, kivéve azoknál a betegeknél, akiknek a GFR-szintje 15-30 ml/ $\min / 1,73 \mathrm{~m}^{2}$, vagy testsúlyuk $>100 \mathrm{~kg}[33,34]$. Amint az INR a megfelelő céltartományt elérte, az áthidaló kezelést le kell állítani [1]. A mechanikus billentyúvel rendelkező betegek esetében a cél-INR-érték függ a beteget meghatározó tényezőktől (például korábbi thromboemboliás esemény vagy pitvarfibrilláció), valamint az implantált protézis thrombogenitasától és a beültetés helyétől (aorta, mitralis vagy tricuspidalis) [28]. A mechanikus aortabillentyúk cél-INR-értékének mediánja 2,5 (2,0$3,0)$, amennyiben nem áll fenn további thromboemboliára utaló kockázati tényező [28, 29, 31]. Javasolt a magasabb cél-INR elérése azoknál a betegeknél, akik kockázati tényezőkkel bírnak (például pitvarfibrilláció, vénás thromboembolia, hiperkoagulábilis állapot vagy bal kamrai ejekciós frakció <35\%) és/vagy mitralis és tricuspidalis billentyúk implantációja kapcsán (medián INR $\geq 3,0)[1,29]$. A mechanikus billentyúvel rendelkező betegek esetében a megfelelő TTR- (terápiás tartományban töltött idő) érték nagyobb biztonságot ad, mint a cél-INR, ez a tény pedig támogatja a betegek saját INRszint-menedzselését [35-37]. A mechanikus billentyúvel élő betegek VKA helyett dabigatránnal történő antikoagulációjának vizsgálata során megnőtt a thromboemboliás és súlyos vérzéssel járó szövődmények aránya, így a vizsgálatot megszakították; a DOAC-oknak jelenleg nincs létjogosultságuk a mechanikus billentyúvel rendelkező betegek antikoagulálásában [38]. Mechanikus billentyű hordozása mellett egyidejűleg fennálló atheroscleroticus betegségben szenvedő betegeknél fontolóra vehető az alacsony dózisú (75-100 mg) ASA alkalmazása a VKA mellett, bár hatásosságának bizonyítékai korlátozottak; szintén szóba jöhet kis dózisú ASA adása a terápiás INR mellett előforduló thromboemboliás epizód esetén [1]. Hármas oralis antithromboticus kezelésre szoruló betegeknél, azaz akiknél mechanikus billentyú mellett a DAPT abszolút indikációja áll fenn (például nemrég végzett PCI vagy ACS), rövid időszak (1 hónap) erejéig mérlegelendő a hármas terápia alkalmazása (VKA + alacsony dózisú ASA és klopidogrél), majd az ASA vagy a klopidogrél elhagyásának mérlegelése szükséges [28]. A tikagrelornak és a praszugrélnek hármas terápiában (azaz VKA mellett) történő alkalmazása kockázatos, nem javasolt [28]. Az ACC/AHA ajánlás alapján, amenynyiben fennáll thrombocytagátló terápia adásának szükségessége, és a vérzéses rizikó alacsonynak tekinthető, mechanikus billentyú antikoagulálására a VKA-terápia mellett mérlegelendő kis dózisú (75-100 mg) ASA adása (IIb/B ajánlás) [29]. Az ACC/AHA ajánlás alapján On-X mechanikus billentyú aortapozícióba való beültetése esetén, amennyiben a beteg nem rendelkezik thromboemboliás rizikófaktorral, az első 3 hónapban 2-3 közötti, majd azt követően 1,5-2 közötti INR-célértékre kell törekednünk alacsony dózisú (75-100 mg/ nap) ASA-terápia kiegészítésével (IIb/B ajánlás) [29, 39].

\section{Biológiai billentyük, billentyüplasztika, egyéb indikációk}

ASA vagy VKA monoterápiában való használata 3 hónap után hasonló eredményeket hozott a mortalitás, a thromboemboliás események és a vérzéses szövődmények tekintetében [40]. Más adatok szerint a VKA az ASA-val szemben nem csökkentette a halálozást vagy a thromboemboliás rizikót, használata azonban szignifikánsan növelte a jelentős vérzés előfordulását [41]. Az ASA és a VKA együttes alkalmazása csökkenti a mortalitást és a thromboembolia veszélyét, azonban szignifikáns mértékben növeli a vérzéses komplikációk előfordulását 
[40]. Amennyiben a mútét utáni első 6 hónap során megtörténik a VKA elhagyása, a thromboemboliás események és a cardiovascularis halálozás incidenciája megemelkedhet, ezt a rizikónövekedést azonban csak a már elindított VKA-terápia megszakítása esetén dokumentálták [42]. Azoknál a pitvarfibrilláló betegeknél, akik biológiai billentyú implantációján estek át, a DOAC-ok a műtét utáni 3. hónaptól használhatók antikoagulálásra [21]. Nincs adatunk a biológiai billentyüt kapó betegek esetében a mütét utáni első 3 hónapot követő időszakot illetően az ASA folytatásának szülkségességéről olyan betegeknél, akiknél nem áll fenn egyéb indikáció az ASA szedésére vonatkozólag [1]. Mitralis vagy tricuspidalis pozícióba implantált biológiai billentyű esetén minden esetben három hónapos VKA-kezelés ajánlott a mútétet követően [1]. Az ACC/AHA ajánlás alapján a biológiai billentyứvel élő betegeknél a kis dózisú (75-100 mg) ASA-terápia hosszú távon adandó (IIa/B ajánlás), továbbá észszerû a biológiai billentyư implantációján átesô, alacsony vérzéses rizikóval bíró betegeket a mütét után 3-6 hónapig VKA-val antikoagulálni, 2,5-ös INRszintet megcélozva, mivel így a mortalitás, a stroke-rizikó és a billentyüthrombosis veszélye egyaránt csökkenthető (IIa/B ajánlás) [39]. Bár az erre vonatkozó bizonyítékaink erősen hiányosak, ajánlott a mütét utáni 3 hónapig tartó, VKA-val történő antikoaguláció mitralisbillentyü- és tricuspidalisbillentyú-plasztika, illetve bil- lentyű beültetésével nem járó aortagyök-plasztika esetén [1]. Azoknál a szívmútéten áteső betegeknél, akiknél a mútét előtt fennálló OAC-terápia indikációja nem billentyúcsere vagy -plasztika volt, a preoperatív VKA- vagy DOAC-kezelést a posztoperatív időszakban újra kell indítani [1]. Az azonnal kialakuló antithromboticus hatása és a fokozott vérzési kockázat miatt a VKA-nak a mútét utáni visszaadásával ellentétben a DOAC-ok visszaadásának különös óvatossággal kell megtörténnie [38]. A fentiekrôl a 3. ábra ad összefoglalót.

\section{Antikoagulálás posztoperatív pitvarfibrilláció esetén}

A korai stroke és halálozás elkerülése érdekében a beteget posztoperatív pitvarfibrilláció esetén antikoagulálni szükséges; az OAC-kezelés csökkenti mind a stroke-rizikót, mind a posztoperatív mortalitást [43]. Nincs arra vonatkozó egyértelmú bizonyíték, hogy mikor kell megkezdeni az antikoagulációt, így a vérzés/thromboembolia kockázatának mérlegelése alapján kell meghozni a döntést. Megfontolandó az UFH vagy az LMWH terápiás dózisának mütét után 12-48 órával való megadása, az OAC-terápiát pedig 48 órával a mútét után kell elindítani, és a beteg $\mathrm{CHA}_{2} \mathrm{DS}_{2}$-VASc pontszámától függően ( $\geq 1$ a férfiak és $\geq 2$ a nők esetében) legalább 4 héten keresztül fenntartani, majd újragondolni szükséges [44].

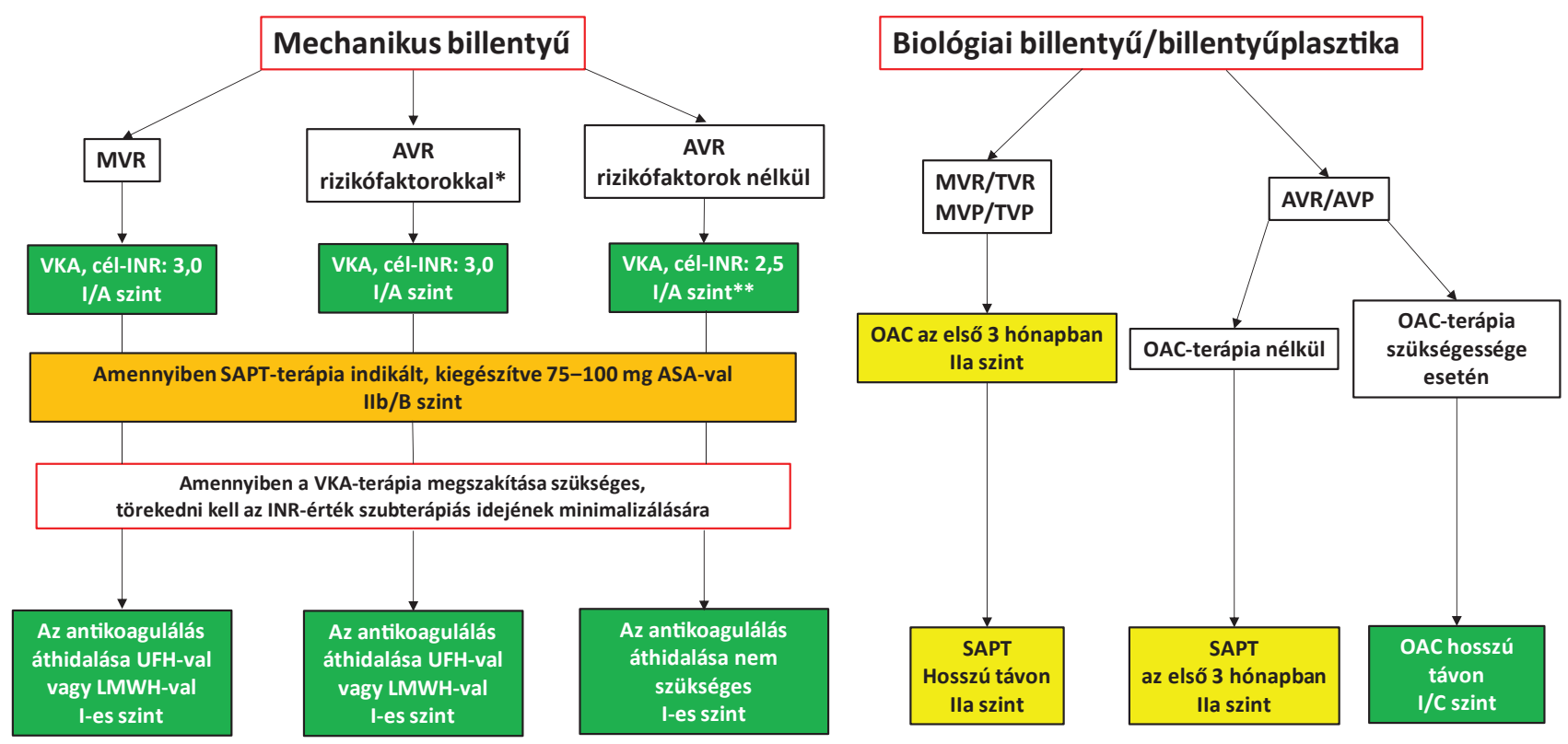

*Pitvarfibrilláció, korábbi thromboemboliás esemény, bal kamrai diszfunkció, korábbi generációs mechanikus billentyű (közepes-magas thrombogenitasú billentyűk: kevéssé tanulmányozott kétlemezes billentyűk, Lillehei-Kaster-billentyű, Omniscience billentyű, Starr-Edwards-billentyű (golyós), Björk-Shiley és egyéb egylemezes billentyűk) **Kivéve On-X mechanikus aortabillentyú esetén, amennyiben nincs egyéb thromboemboliás rizikófaktor. Ekkor az első 3 posztoperativ hónapban a cél-INR 2-3, majd a cél-INR 1,5-2, kiegészítve $100 \mathrm{mg}$ ASA-val (IIb/B szint)

3. ábra $\quad$ Az antikoaguláció módja múbillentyú-beültetést/billentyúplasztikát követően (az EACTS módosított ábrája [1])

ASA = acetilszalicilsav; AVP = aortabillentyú-plasztika; AVR = aortabillentyü-csere; EACTS = Európai Szív-Mellkas Sebészeti Társaság; INR = nemzetközi normalizált ráta; $\mathrm{LMWH}=$ kis molekulatömegú heparin; $\mathrm{MVP}=$ mitralisbillentyú-plasztika; $\mathrm{MVR}=$ mitralisbillentyú-csere; $\mathrm{OAC}=$ oralis antikoaguláns; SAPT = egyszeres thrombocytagátló terápia; TVP = tricuspidalisbillentyú-plasztika; TVR = tricuspidalisbillentyú-csere; UFH = nem frakcionált heparin; VKA = K-vitamin-antagonista 
A posztoperatív pitvarfibrilláció antikoagulációját illetően a legtöbb bizonyítékot a VKA kapcsán írták le, mechanikus billentyü implantációját követően és közepesen súlyos vagy súlyos mitralis stenosis esetén ez az ajánlott szer [44]. Bizonyított, hogy nonvalvularis pitvarfibrilláció esetén és biológiai billentyű implantációja után fellépő pitvarfibrilláció kapcsán a DOAC-ok használata előnyösebb a VKA-val szemben [45].

\section{Thrombosisprofilaxis szívmütétet követően}

18000 , szívmútéten átesett beteg posztoperatív ultrahangvizsgálati és venográfiai adatainak metaanalízise alapján a mélyvénás thrombosis előfordulása $22 \%$, a proximalis mélyvénás thrombosisé $15 \%$, a pulmonalis embolia gyakorisága $0,8 \%$, a halálos pulmonalis embolia előfordulása $0,16 \%$ [46]. A posztoperatív időszakban adott, profilaktikus mennyiségú UFH vagy LMWH szívmútét után jelentősen csökkenti a morbiditást azáltal, hogy csökkenti a mélyvénás thrombosis és a tüdőembolia előfordulását [47]. $5000 \mathrm{NE} \mathrm{LMWH} \mathrm{adásával} \mathrm{és}$ kompressziós harisnya használatával a pulmonalis embolia gyakorisága 4\%-ról 1,5\%-ra csökkenthető [48]. Minden egyes, szívmútéten áteső betegnek profilaktikus dózisú LMWH-t szükséges adni a mútétet követő időszakban az első posztoperatív naptól kezdve (Ia/B-Ib/B ajánlás) [49]. A betegek nappali nagyobb aktivitására való tekintettel a profilaktikus LMWH-t célszerü este megadni.

\section{Vérzésveszély a szívmütét perioperatív szakában}

A súlyos vérzés kockázata jelentősen növekszik, ha a beteg INR-je meghaladja a 4,5-öt, és exponenciálisan növekszik tovább 6,0 feletti INR esetén [28]. Amennyiben vérzés nem lépett fel, a magas INR-szint kezelése az aktuális INR-szinttől és az éppen használt VKA felezési idejétől függ. Ilyenkor módunk van leállítani az oralis antikoagulációs kezelést és figyelemmel követni az INR fokozatos csökkenését, vagy adhatunk per os K-vitamint (1 vagy 2 mg-os dózisokban) [50]. A magas INR-szint kapcsán történő azonnali beavatkozás intravénás protrombinkomplex-koncentrátum és K-vitamin alkalmazásával csak olyan súlyos vérzés fellépése esetén szükséges, amely lokálisan nem kontrollálható, veszélyezteti az életet vagy fontos szervi funkciókat (például intracranialis vérzés), hemodinamikai instabilitást okoz, esetleg akut mütéti beavatkozást vagy transzfúziót igényel [50]. A mechanikus billentyúvel élö, aktuálisan vérzést nem mutató betegeknél kialakult szupraterápiás INR $(>5,0)$ előfordulása esetén a VKA ideiglenes megvonása mellett az oralis K-vitaminnal végzett egyéni kezelés előnyei bizonytalanok (IIb/C szintü evidencia) [29].

A kisebb, vérzés szempontjából könnyen szabályozható beavatkozásokon (például foghúzás, szürkehályog- mútét) áteső, mechanikus szívbillentyưvel rendelkező betegeknél ajánlott a VKA-val történő antikoaguláció terápiás INR-rel történő folytatása (I/C ajánlás) [29]. Az invazív beavatkozásokon áteső, kétlemezes mechanikus aortabillentyúvel rendelkező betegeknél, akik esetében nem áll fenn egyéb thromboemboliás rizikófaktor, ajánlott a VKA-val történő antikoaguláció ideiglenes felfüggesztése szubterápiás INR mellett, áthidaló terápia alkalmazása nélkül (I/C ajánlás) [29]. Az invazív beavatkozásokon áteső, mechanikus aortabillentyúvel rendelkező betegeknél, akik esetében további thromboemboliás rizikófaktor áll fenn, vagy régebbi típusú mechanikus aortabillentyúvel vagy mitralis mechanikus múbillentyúvel rendelkeznek, megfontolandó a VKA-val történő antikoaguláció ideiglenes felfüggesztése és szubterápiás INR mellett egyéni áthidaló terápia alkalmazása, melyet az esetleges thromboemboliás/vérzéses szövődmények mérlegelése alapján szükséges kialakítani [29].

A fentiekben a legutóbbi ajánlások alapján bemutattuk a thrombocytagátló és antikoagulációs terápia szívsebészeti területhez kapcsolódó iránymutatásait. Figyelembe veendő, hogy a jelen információk folyamatos frissítésen mennek keresztül, a fenti javaslatok csupán a jelen helyzetet mutatják be.

Megjegyzés. Az idevonatkozó nemzetközi ajánlások magyar nyelvű megfelelőit a szerzők készséggel megküldik az érdeklődőknek.

Anyagi támogatás: A cikk megírásához anyagi támogatásban egyik szerző sem részesült.

Szerzôi munkamegosztás: T. R.: Irodalomkutatás, a cikk megírása. N. Z.: Kardiológiai szakmai véleményezés. R. A.: Szívsebészeti szakmai véleményezés. A cikk végleges változatát valamennyi szerző elolvasta és jóváhagyta.

Érdekeltségek: A szerzőknek nincsenek érdekeltségeik.

\section{Irodalom}

[1] Sousa-Uva M, Head SJ, Milojevic M, et al. 2017 EACTS guidelines on perioperative medication in adult cardiac surgery. Eur J Cardiothorac Surg. 2018; 53: 5-33.

[2] Gombocz K, Beledi Á, Botos F, et al. Successful combined application of reoperation protocol with target-guided hemostatic therapy for the treatment of severe bleeding in cardiac surgical patients. [Reoperációs algoritmus és célvezérelt haemostasisterápia együttes, sikeres alkalmazása súlyos szívsebészeti vérzés kezelésében.] Orv Hetil. 2020; 161: 1414-1422. [Hungarian]

[3] Galas FR, Almeida JP, Fukushima JT, et al. Blood transfusion in cardiac surgery is a risk factor for increased hospital length of stay in adult patients. J Cardiothorac Surg. 2013; 8: 54.

[4] Hastings S, Myles P, McIlroy D. Aspirin and coronary artery surgery: a systematic review and meta-analysis. Br J Anaesth. 2015; 115: 376-385.

[5] Deja MA, Kargul T, Domaradzki W, et al. Effects of preoperative aspirin in coronary artery bypass grafting: a double-blind, placebo-controlled, randomized trial. J Thorac Cardiovasc Surg. 2012; 144: 204-209. 
[6] Nenna A, Spadaccio C, Prestipino F, et al. Effect of preoperative aspirin replacement with enoxaparin in patients undergoing primary isolated on-pump coronary artery bypass grafting. Am J Cardiol. 2016; 117: 563-570.

[7] Zisman E, Erport A, Kohanovsky E, et al. Platelet function recovery after cessation of aspirin: preliminary study of volunteers and surgical patients. Eur J Anaesthesiol. 2010; 27: 617-623.

[8] Mangano DT, Multicenter Study of Perioperative Ischemia Research Group. Aspirin and mortality from coronary bypass surgery. N Engl J Med. 2002; 347: 1309-1317.

[9] Musleh G, Dunning J. Does aspirin $6 \mathrm{~h}$ after coronary artery bypass grafting optimise graft patency? Interact Cardiovasc Thorac Surg. 2003; 2: 413-415.

[10] Wallentin L, Becker RC, Budaj A, et al. Ticagrelor versus clopidogrel in patients with acute coronary syndromes. N Engl J Med. 2009; 361: 1045-1057.

[11] Wiviott SD, Braunwald E, McCabe $\mathrm{CH}$, et al. Prasugrel versus clopidogrel in patients with acute coronary syndromes. $\mathrm{N} \mathrm{Engl} \mathrm{J}$ Med. 2007; 357: 2001-2015.

[12] Kolh P, Windecker S, Alfonso F, et al. 2014 ESC/EACTS Guidelines on myocardial revascularization: the Task Force on Myocardial Revascularization of the European Society of Cardiology (ESC) and the European Association for Cardio-Thoracic Surgery (EACTS). Developed with the special contribution of the European Association of Percutaneous Cardiovascular Interventions (EAPCI). Eur J Cardiothorac Surg. 2014; 46: $517-$ 592.

[13] Ferraris VA, Saha SP, Oestreich JH, et al. 2012 update to the Society of Thoracic Surgeons guideline on use of antiplatelet drugs in patients having cardiac and noncardiac operations. Ann Thorac Surg. 2012; 94: 1761-1781.

[14] Valgimigli M, Bueno H, Byrne RA, et al. 2017 ESC focused update on dual antiplatelet therapy in coronary artery disease developed in collaboration with EACTS. Eur J Cardiothorac Surg. 2018; 53: 34-78.

[15] Verma S, Goodman SG, Mehta SR, et al. Should dual antiplatelet therapy be used in patients following coronary artery bypass surgery? A meta-analysis of randomized controlled trials. BMC Surg. 2015; 15: 112 .

[16] Fox KA, Mehta SR, Peters R, et al. Benefits and risks of the combination of clopidogrel and aspirin in patients undergoing surgical revascularization for non-ST-elevation acute coronary syndrome: the clopidogrel in unstable angina to prevent recurrent ischemic events (CURE) trial. Circulation 2004; 110: 12021208.

[17] Hansson EC, Jidéus L, Åberg B, et al. Coronary artery bypass grafting-related bleeding complications in patients treated with ticagrelor or clopidogrel: a nationwide study. Eur Heart J. 2016; 37: 189-197.

[18] Wallentin L. P2 $\mathrm{Y}_{12}$ inhibitors: differences in properties and mechanisms of action and potential consequences for clinical use. Eur Heart J. 2009; 30: 1964-1977.

[19] Fitchett D, Eikelboom J, Fremes S, et al. Dual antiplatelet therapy in patients requiring urgent coronary artery bypass grafting surgery: a position statement of the Canadian Cardiovascular Society. Can J Cardiol. 2009; 25: 683-689.

[20] Pagano D, Milojevic M, Meesters MI, et al. 2017 EACTS/ EACTA guidelines on patient blood management for adult cardiac surgery. Eur J Cardiothorac Surg. 2018; 53: 79-111.

[21] Heidbuchel H, Verhamme P, Alings M, et al. Updated European Heart Rhythm Association practical guide on the use of non-vitamin $\mathrm{K}$ antagonist anticoagulants in patients with non-valvular atrial fibrillation. Europace 2015; 17: 1467-1507.

[22] Douketis JD, Spyropoulos AC, Kaatz S, et al. Perioperative bridging anticoagulation in patients with atrial fibrillation. $\mathrm{N}$ Engl J Med. 2015; 373: 823-833.

[23] Jones HU, Muhlestein JB, Jones KW, et al. Preoperative use of enoxaparin compared with unfractionated heparin increases the incidence of re-exploration for postoperative bleeding after open-heart surgery in patients who present with an acute coronary syndrome: clinical investigation and reports. Circulation 2002; 106(12 Suppl 1): I19-I22.

[24] O'Donnell MJ, Kearon C, Johnson J, et al. Brief communication: preoperative anticoagulant activity after bridging lowmolecular-weight heparin for temporary interruption of warfarin. Ann Intern Med. 2007; 146: 184-187.

[25] Kozek-Langenecker SA, Afshari A, Albaladejo P, et al. Manage ment of severe perioperative bleeding: guidelines from the European Society of Anaesthesiology. Eur J Anaesthesiol. 2013; 30: 270-382.

[26] Pernod G, Albaladejo P, Godier A, et al. Management of major bleeding complications and emergency surgery in patients on long-term treatment with direct oral anticoagulants, thrombin or factor-Xa inhibitors: proposals of the Working Group on Perioperative Haemostasis (GIHP) - March 2013. Arch Cardiovasc Dis. 2013; 106: 382-393.

[27] Levy JH, Spyropoulos AC, Samama CM, et al. Direct oral anticoagulants: new drugs and new concepts. JACC Cardiovasc Interv. 2014; 7: 1333-1351.

[28] Falk V, Baumgartner H, Bax JJ, et al. Corrigendum to 2017 ESC/EACTS guidelines for the management of valvular heart disease. Eur J Cardiothorac Surg. 2017; 52: 616-664. [Erratum: Eur J Cardiothorac Surg. 2017; 52: 832.]

[29] Otto CM, Nishimura RA, Bonow RO, et al. 2020 ACC/AHA guideline for the disease management of patients with valvular heart: a report of the American College of Cardiology/American Heart Association Joint Committee on Clinical Practice Guidelines. J Am Coll Cardiol. 2021; 77: e25-e197. [Erratum: J Am Coll Cardiol. 2021; 77: 509.] [Erratum: J Am Coll Cardiol. 2021; 77: 1275.]

[30] Pfliegler Gy. Reducing and therapy of the risk of thromboembolism. [A thromboembolia kockázatának csökkentése és kezelése.] Orv Hetil. 2009; 150: 2335-2403. [Hungarian]

[31] Iung B, Rodés-Cabau J. The optimal management of antithrombotic therapy after valve replacement: certainties and uncertainties. Eur Heart J. 2014; 35: 2942-2949.

[32] Meurin P, Tabet JY, Weber H, et al. Low-molecular-weight heparin as a bridging anticoagulant early after mechanical heart valve replacement. Circulation 2006; 113: 564-569.

[33] Roffi M, Patrono C, Collet JP, et al. 2015 ESC guidelines for the management of acute coronary syndromes in patients presenting without persistent ST-segment elevation: task force for the management of acute coronary syndromes in patients presenting without persistent ST-segment elevation of the European Society of Cardiology (ESC). Eur Heart J. 2016; 37: 267-315.

[34] Nishimura RA, Otto CM, Bonow RO, et al. 2014 AHA/ACC guideline for the management of patients with valvular heart disease: a report of the American College of Cardiology/American Heart Association Task Force on Practice Guidelines. J Am Coll Cardiol. 2014; 63: e57-e185. [Erratum: J Am Coll Cardiol. 2014; 63: 2489.]

[35] Grzymala-Lubanski B, Svensson PJ, Renlund H, et al. Warfarin treatment quality and prognosis in patients with mechanical heart valve prosthesis. Heart 2017; 103: 198-203.

[36] Heneghan C, Ward A, Perera R, et al. Self-monitoring of oral anticoagulation: systematic review and meta-analysis of individual patient data. Lancet 2012; 379: 322-334.

[37] Head SJ, Celik M, Kappetein AP. Mechanical versus bioprosthet ic aortic valve replacement. Eur Heart J. 2017; 38: 2183-2191.

[38] Eikelboom JW, Connolly SJ, Brueckmann M, et al. Dabigatran versus warfarin in patients with mechanical heart valves. $\mathrm{N}$ Engl J Med. 2013; 369: 1206-1214

[39] Nishimura RA, Otto CM, Bonow RO, et al. 2017 AHA/ACC focused update of the 2014 AHA/ACC guideline for the management of patients with valvular heart disease: a report of the American College of Cardiology/American Heart Association 
Task Force on Clinical Practice Guidelines. Circulation 2017; 135: el159-ell195

[40] Brennan JM, Edwards FH, Zhao Y, et al. Early anticoagulation of bioprosthetic aortic valves in older patients: results from the Society of Thoracic Surgeons Adult Cardiac Surgery National Database. J Am Coll Cardiol. 2012; 60: 971-977.

[41] Rafiq S, Steinbrüchel DA, Lilleør NB, et al. Antithrombotic therapy after bioprosthetic aortic valve implantation: warfarin versus aspirin, a randomized controlled trial. Thromb Res. 2017; 150: 104-110

[42] Merie C, Køber L, Skov Olsen P, et al. Association of warfarin therapy duration after bioprosthetic aortic valve replacement with risk of mortality, thromboembolic complications, and bleeding. JAMA 2012; 308: 2118-2125.

[43] Gialdini G, Nearing K, Bhave PD, et al. Perioperative atrial fibrillation and the long-term risk of ischemic stroke. JAMA 2014; 312: 616-622.

[44] Kirchhof P, Benussi S, Kotecha D, et al. 2016 ESC Guidelines for the management of atrial fibrillation developed in collaboration with EACTS. Eur J Cardiothorac Surg. 2016; 50: el-e88.

[45] Giugliano RP, Ruff CT, Braunwald E, et al. Edoxaban versus warfarin in patients with atrial fibrillation. N Engl J Med. 2013; 369: 2093-2104.
[46] Shammas NW. Pulmonary embolus after coronary artery bypass surgery: a review of the literature. Clin Cardiol. 2000; 23: 637644.

[47] Close V, Purohit M, Tanos M, et al. Should patients post-cardiac surgery be given low molecular weight heparin for deep vein thrombosis prophylaxis? Interact Cardiovasc Thorac Surg. 2006; 5: 624-629.

[48] Ramos R, Salem BI, De Pawlikowski MP, et al. The efficacy of pneumatic compression stockings in the prevention of pulmonary embolism after cardiac surgery. Chest 1996; 109: 82-85.

[49] Dunning J, Versteegh M, Fabbri A, et al. Guideline on antiplatelet and anticoagulation management in cardiac surgery. Eur J Cardiothorac Surg. 2008; 34: 73-92.

[50] Pernod G, Godiér A, Gozalo C, et al. French clinical practice guidelines on the management of patients on vitamin $\mathrm{K}$ antagonists in at-risk situations (overdose, risk of bleeding, and active bleeding). Thromb Res. 2010; 126: el67-e174.

(Tóth Roland dr., Zalaegerszeg, Zrínyi Miklós út 1., 8900 e-mail: roland.toth.sopron@gmail.com)

\section{MEGHÍ Vó}

\section{Az Észak-Közép-budai Centrum, Új Szent János Kórház és Szakrendelő Tudományos Bizottsága} tisztelettel meghívja az érdeklődőket a következő tudományos ülésére,

melyet az I. Belgyógyászati és Gasztroenterológiai Osztály és a Magyar Gasztroenterológiai Társaság rendez.

\section{Időpont: 2021. december 1. (szerda) 14.00 óra \\ Helyszín: Szent János Kórház Auditóriuma - 1125 Budapest, Diós árok 1-3. Üléselnök: Dr. Székely György és Dr. Pusztay Margit}

\section{Program: „Aktualitások a hepatogasztroenterológiában”}

Pusztay Margit dr. (I. Belgyógyászati Osztály, Hepatológiai Szakambulancia):

„Anti-HCV-pozitív vagyok!” Egy téveszme eloszlatása - Regöly-Mérei János-emlékelöadás

15 perc

Székely György dr. (I. Belgyógyászati és Gasztroenterológiai Osztály):

A hazai endoszonográfia kiemelkedő alakja: Dr. Winternitz Tamás (1957-2021)

10 perc

Horváth Gábor dr. (I. Belgyógyászati Osztály, Hepatológiai Szakambulancia):

A COVID-19- vírusfertőzés jelentősége a hepatológiában

15 perc

Németh Alíz dr. (I. Belgyógyászati Osztály, Hepatológiai Szakambulancia):

Szarvashibák a májfunkciós értékek diagnosztikájában

15 perc

\section{Interaktív kerekasztal}

$$
\text { VITA - BÜFÉ }
$$

Minden érdeklődőt szeretettel várunk!
Prof. Dr. Hirschberg Andor
Dr. Székely György
c. egyetemi tanár,
osztályvezető föorvos

a Tudományos Bizottság elnöke

A cikk a Creative Commons Attribution 4.0 International License (https://creativecommons.org/licenses/by/4.0/) feltételei szerint publikált Open Access közlemény, melynek szellemében a cikk bármilyen médiumban szabadon felhasználható, megosztható és újraközölhető, feltéve, hogy az eredeti szerző és a közlés helye, illetve a CC License linkje és az esetlegesen végrehajtott módosítások feltüntetésre kerülnek. (SID_1) 